IFLA J ournal, 17 (3), August 1991, 209, 241-247

\title{
Teaching Online I nformation Systems: Perspectives on the British Experience
}

Ian M. Johnson

\section{I ntroduction}

The original aim of this paper was to review the development of education and training for online searching in Britain during the last ten years. The literature is fairly comprehensive in its coverage of the evolution of online searching, and of new developments such as OPACs (Online Public Access Catalogues), CD-ROM systems, expert systems, and image storage systems. It would have been possible to write a book on these topics but that task has already been completed by the authors of no less than three books which have appeared in Britain. ${ }^{1,2,3}$

The different approaches which have been taken to aspects of education and training, including the development of simulations and the place of online searching in the curriculum have also been thoroughly considered. After completing an initial review of this extensive literature, it became apparent that it would probably be most useful to draw attention to a number of issues which do not appear to have been widely discussed.

Certain aspects of the British experience could be of particular significance for future development in those countries where online searching is not yet as widely practiced. These relate particularly to the impact of assistance and encouragement for experimental research; the impact of end-users' appreciation of the potential of online information services; and the implications of teaching online systems (and other forms of library automation) for curriculum development, student recruitment, funding, and the position of the Schools of Librarianship within their parent institution. These issues are not fully discussed in the existing literature, but have a long-term significance far greater than the solution of the technical problems associated with online searching. The paper therefore attempts to highlight some of those issues, drawing upon the literature and the author's observations of developments in Britain in the last ten years.

\section{Experimental Online Searching and the Development of Library Services}

The first online systems came into general use in Britain nearly 20 years ago. The National Library of Medicine MEDLI NE service became available in 1971, and Lockheed launched DIALOG as a commercial service in 1972. The international telecommunications systems necessary to gain access to these services from Britain were already in existence. The subsequent introduction of telecommunications networks dedicated to access to online systems led to a rapid increase in online searching.

These technological developments coincided with the establishment in 1972/74 of the British Library, bringing together as one organization various elements of national library services which had previously been independent of each other. 
One of these agencies was the Office for Scientific and Technical Information (OSTI), which was mainly an agency for funding research on behalf of the government's Department of Education and Science. This became the British Library Research and Development Department (BLR\&DD).

In 1973 OSTI established an experimental programme in a number of libraries in universities and other institutions of higher education to assess the potential use of online services for medical and for other scientific and technical information retrieval. ${ }^{4}$ OSTI provided some assistance towards the cost of the providing the necessary equipment and of conducting the searches. In 1977/78, as OSTI's successor, the BLR\&DD agreed to support a similar series of experimental projects in public libraries (which in Britain offer a wide range of information services to the local business and professional community as well as cultural and educational services).5 The BLR\&DD has subsequently involved itself in supporting experimental approaches to teaching online systems in the Schools of Librarianship and Information Studies, and in encouraging pupils in secondary schools to use online systems.

The aim of the initial programmes of funded research activity was to identify guidelines for the most effective introduction and use of online systems. They also considerably encouraged interest in the provision and use of online services. There is now no university or polytechnic library service which does not offer online search facilities to its users. More than half of the public library systems in the country also offer this service. Specialist libraries and information services are major users of online services, particularly for financial and other business information. Britain has become the largest consumer of online services in Western Europe, accounting for about one-third of the total European market. The annual expenditure on online searching by British libraries and information services has been estimated at about USD 245,000,000. Perhaps only 10 of this comprised the cost of searches for textual or bibliographic data.

The encouragement of online service development in the medical field also had a significant impact on the development of medical library services. The early experimental work on online services in medical libraries ${ }^{6}$ showed that only about one-fourth of the end-users involved in those experiments preferred to conduct online searches themselves without any assistance from a professional intermediary. It also confirmed that search costs were generally lower when the search was prepared and carried out by or with assistance from a professional intermediary. Perhaps the most encouraging result of the research was that $89 \%$ of the end-users could see uses for online information retrieval where they might previously have ignored the literature completely.

Nonetheless, the provision of online information services has served as a spur to the use of secondary information sources, and it seems likely that the growth of CD-ROM products will have a similar, possibly a greater effect. In a recent study of users of CD-ROM products, 75 found them easier to use than the equivalent printed index. Moreover, 34 of users of CD-ROM databases found them essential to research.

The development and marketing of biomedical database services has certainly had a significant impact on the attitude of medical and paramedical practitioners towards the use and provision of information services. The professional 
associations responsible for overseeing the standards of medical education in Britain are also responsible for the standards of post-graduate medical education provided for doctors working in hospitals. They will not now approve a hospital as a post-graduate training centre unless amongst its facilities it includes adequate library services. If a hospital is not an approved post-graduate training centre, it has considerable difficulty in recruiting doctors, because their future promotion depends on undergoing approved post-graduate education . One result is that now only the smallest hospitals in Britain do not employ a professionally qualified librarian.

\section{End-users of Online Systems and the Development of Library Services}

Because of the initially small number of users in Britain, training by the service providers was limited in its availability, and even in the early 1980s the schools of librarianship were still a major source of training for medical librarians and others who wished to introduce online services. However, as the British market for online services developed, the major hosts established their own training facilities in Britain, and these now provide a significant number of short courses each year, aimed at introducing new users or providing advanced training for experienced users. The development of these programmes of courses in Britain was closely allied to the establishment of marketing and sales staff in Britain by the online service providers, and the training is often conducted by the people who sell or support the systems.

Most of the major online service hosts are commercial organizations, which judge their success by the growth in the size of their business each year, and judge the success of each unit within the business by its ability to make at least enough profits to cover its own operating costs. Their decisions to employ staff in Britain were therefore not based simply on meeting the needs of their existing customers in Britain. They also expected that their staff would find new customers. Many of the organizations which were seen as potential buyers of online services did not employ librarians or information specialists. The promotion of sales was, therefore, directed at the end-users.

For example, when the first legal databases were introduced, very few of the commercial partnerships of lawyers employed librarians. Their reaction to the introduction of legal databases was similar to that of the medical professions. As a result of the marketing activity of the online service providers, the lawyers suddenly became aware of the potential of information and of the competitive advantage that better information might give them in legal disputes. However, the lawyers found that they themselves generally used the online facilities so infrequently that they did not develop any expertise. They needed professional intermediaries to use the online services and to obtain other secondary information. Consequently, in one two-year period in the middle of the 1980s, some 200 new jobs for professional librarians were created by the legal partnerships in the City of London. This growth has continued, and has spread to almost all the other cities in Britain. Moreover, the lawyers recognize the contribution to their successes in legal disputes which are made by their librarians, and they are rewarding them with high salaries.

\section{Curriculum and Resources for Teaching Online Searching}


The Schools of Librarianship quickly incorporated online searching into their curricula. It has to be remembered that at the time online searching was introduced, there were very few online services available; it called for practical skills which were outside the experience of most librarians; training facilities were minimal; there was no general standard for microcomputers; and there had been no previous expenditure on this kind of activity.

Attention initially focused on the resources required tor this aspect of education and training. Teaching staff had to develop the necessary skills. The necessary equipment had to be acquired. The cost of access to online services by teaching staff and students had to be held down. Much effort went into the development of microcomputer simulations of online searching to train users at minimal cost before they were permitted to undertake searches online. These efforts were aided by BLR\&DD support for experimental research into the development of new teaching methodologies. Unfortunately, a lot of the work which went into developing the early simulations was wasted because there was no widely accepted standard microcomputer and the schools had different levels of funding. Consequently each acquired equipment which was not always compatible with that in other schools.

However, the circumstances in which teaching now takes place are very different. There are now about 600 online search services available, offering access to about 4,000 databases. Most teachers of librarianship have some familiarity with using computers and with online searching. Training facilities are widely available. They are provided not only by the schools of librarianship, but also by the online service providers, and by other agencies. The equipment is also widely available, and relatively inexpensive. The introduction of the IBM Personal Computer in 1980 established an increasingly accepted standard for microcomputers, permitting the wider distribution of search simulations. However, the budgets of the schools of librarianship are limited, and the cost of online searching still has to be kept down.

The current place of teaching online in the curricula of the British Schools of Librarianship has recently become a matter for debate and reconsideration. The schools do not have the funds to support considerable live searching by their students, and generally believe that because of the range of services now available and the rapid pace of changes in this field, experience might be more appropriately developed in short in-service training courses relate ${ }^{\wedge}$ to specific service providers or databases. Some teaching staff also believe that online has diverted attention and resources from more critical areas of the information discipline, and that there has been a regression to the early days of education for librarianship. They are concerned that the distinctive professional elements of higher education, the principles and theories of information retrieval, have been subordinated to a necessarily limited training in practical skills. ${ }^{7}$ On the other hand, it is recognized that many students enter the schools of librarianship with little experience of computers, despite the government's attempts to support the provision of microcomputers in schools. Moreover, employers in the special library sector are making it abundantly clear to the schools of librarianship that they prefer to employ new staff who have had ample experience of online searching. 
The major online service providers now appear to be offering the schools a way out of part of this dilemma. For some years DIALOG has offered access to databases at reduced charges for students in the schools of librarianship. For the last two years, DATASTAR has offered registered students ample time to use their services free of charge. This year BRS has begun to offer similar facilities. Clearly the service providers now recognize the role which the schools of librarianship play in developing their future customers. This freer access to databases will permit the schools to allow their students to conduct practical exercises online almost as freely as they currently use books in a reference library. The willingness of some suppliers of CD-ROM services to make out-ofdate compact discs available free of charge to the schools of librarianship for teaching purposes will offer similar benefits.

\section{The Financial, Political, and Organizational I mplications of Online Searching}

Before the commercial companies began to see that it was in their interests to assist the schools of librarianship, the schools had conducted a long campaign to persuade the government to provide additional financial support for the teaching of librarianship and information studies. This battle began in the early 1980s when the government introduced new procedures for funding higher education. The former procedure had been based on simply revising the existing overall budgets of the Universities and Polytechnics, which were based on nothing more than historic precedents. Consequently there had been wide variations in expenditure in how much each institution received, and how much was internally allocated to the schools of librarianship. This was changed so that throughout the country, each institution was granted a fixed amount for each student. The only variation was that the amount was fixed according to the subject being studied.

Initially the government took a traditional view of the costs of teaching librarianship. However, following a review in 1986s there began to be some acceptance of the idea that the costs of teaching librarianship were high, and similar to the costs of teaching computer science. Since then the government appears to have begun to change its mind again, probably because of the implications of the overall limits being set on expenditure on education. Attention is now being drawn, for example, to the near universal application of computers to teaching in all disciplines as a reason for not permitting increased funding for teaching subjects which include computer applications.

To draw attention to the changing nature of librarianship, many of the Schools of Librarianship changed their names during the 1980s, and became Schools of Librarianship and Information Studies. This was intended not only to help them stake a claim for a higher level of financial support, but also to try to assist in the recruitment of students. Many also changed the nature of their courses to try to meet what they saw as the changing needs of the existing employers and the emerging opportunities for employment using information technology.

Despite these changes, during the 1980s, the number of students enrolling in many of the schools of librarianship and information studies has slowly declined. The current generation of young people in Great Britain is much more materialistic in its ambitions than the previous generation, and librarianship is 
still not a profession which offers good salaries in comparison with those offered to graduation in other disciplines. Whilst the rewards of the emerging job market for information professionals may have attracted some new and different kinds of students, it seems that more of those formerly attracted to traditional librarianship have been repelled either by the low salaries or perhaps by the introduction of information technology. It may simply be that they are confused about what kind of career the courses will prepare them for; some employers in the "traditional" libraries are certainly confused about what their potential new recruits are being prepared for.

The Universities and Polytechnics in Britain have been undergoing major changes in the last couple of years. This is partly a response to the government's changes in the financial arrangements. It is also in anticipation of the changes in the higher education system which are arising from the decline in the number of young people. At the same time as implementing measures to attract different kinds of students, the Universities and Polytechnics are trying to reduce their expenditure. One approach has been to amalgamate schools within institutions, in order to create academic groupings capable of producing new interdisciplinary courses and to economize on the number of senior posts.

This has already affected a number of the schools of librarianship and information studies. The schools' propaganda about the future career prospects for information professionals and the inter-disciplinary nature of their subject have worked against them. Six or seven of the 16 schools have lost their separate identity in some broader grouping of "information studies" or "informatics". Librarianship and information studies are not the dominant elements in these new groupings, and the future direction of their development clearly will not emphasize librarianship. Some concern is consequently being expressed about the future of their courses in librarianship, and how the requirements of a large existing job market will be met.

Nonetheless, some schools do seem to have prospered during this period.Their common feature appears to be that they have not attempted to adapt a single course to meet the all needs of the variety of different jobs which now require skills in using information technology. They have instead offered a variety of courses aimed at specific job markets but with some common elements, including appropriate aspects of information technology.

\section{Conclusions}

This review has explained how generous funding of the experimental introduction of online services and of teaching online information systems has had a beneficial effect, not only on the growth of online information retrieval, but also on the development of library and information services. The education of end-users of online information services (through their involvement in experimental research, and through the marketing activities of the online service providers) has also made them aware of the potential of library and information services, far more than the promotion of traditional print-based services has achieved. End-users, who usually have a greater influence on the development of library and information services than librarians, seem far more supportive of services which offer them access to the range of material which can be revealed quickly, easily, and accurately by online searching or CD-ROM. It is clearly important for the 
schools of librarianship and information studies and for librarians generally to be active in demonstrating online and CD-ROM services to all potential end-users as a way of encouraging the future growth of libraries.

This review has also drawn attention to significant problems encountered by the schools of librarianship and information studies. The introduction of information technology had an immediate impact on the curriculum, but the rapid pace of technological change has highlighted the need for the schools to maintain a balance between teaching principles and providing practical experience. Teaching online systems (and other forms of library automation) has had significant implications for the funding of the schools of librarianship, but any benefits seem to have been short-lived. The inter-disciplinary nature of online information and "information studies" has been recognized, but not always to the advantage of the schools of librarianship and information studies. Clearly, those schools which have yet to develop teaching in online (and those which are fully engaged in the subject) will need to give some thought not only to their curricular plans and their immediate need for resources, but also to longer-term strategic issues such as their portfolio of courses, student recruitment, and institutional politics and organization.

\section{References}

1 Convey, J. Online Information Retrieval: An Introductory Manual of Principles and Practice, 3rd ed. London: Bingley, 1989.

2 Hartley, R.J. et al. Online Searching: Principles and Practice. London: Bowker-Saur, 1989.

3 Haygarth-Jackson, A., ed. Training and Education for Online. London: Taylor Graham, 1989.

4. Holmes, P.L. Online Information Retrieval: An Introduction to the British Library's Short-Term Experimental Information Network Project. London: BLR\&DD. 2 vols. (Vol. 1, 1977. Report no. 5360 HC. Vol. 2, 1988. Report no. 5397).

5. Moore, N. Online Information in Public Libraries: A Review of Recent British Research. London: BLR\&DD, 1982. (Report no. 5648).

6. Reported in "Library and Information News", March 1990, p. 6 of an article by Juhl and Larry in The Serials Librarian 17: 69-80 (1990).

7. Roberts, N. "Online: An Educational Cul-de-sac?" Education for Information, 7: 101106 (1989).

8. University Grants Commission and National Advisory Body for Higher Education. Transbinary Group on Librarianship and Information Studies. Report. London: UGC/NAB, 1986.

\section{About the author}

Ian M. Johnson is Chairman of the IFLA Section on Education and Training, and Head of the School of Librarianship and Information Studies, Robert Gordon's Institute of Technology, Hilton Place, Aberdeen AB9 1FP, Scotland, UK. 